\title{
Bacterial etiology of necrotic spots on leaves and shoots of grapevine (Vitis vinifera $\mathrm{L}$.) in Poland
}

\author{
Artur Mikiciński • Joanna Puławska • \\ Monika Kałużna • Paweł Trzciński • \\ Aleksander Wąsikowski • Piotr Sobiczewski
}

Accepted: 29 January 2020 / Published online: 12 February 2020

(C) The Author(s) 2020
Electronic supplementary material The online version of this article (https://doi.org/10.1007/s10658-020-01943-9) contains supplementary material, which is available to authorized users.

A. Mikiciński · J. Puławska • M. Kałużna · P. Trzciński • P. Sobiczewski $(\bowtie)$

Research Institute of Horticulture, ul. Konstytucji 3 Maja 1/3, 96-100 Skierniewice, Poland

e-mail: piotr.sobiczewski@inhort.pl

A. Wąsikowski

Plant Nursery PLANT-WIN, ul. Jagielska 45, 02-886 Warsaw, Poland
Keywords Pseudomonas syringae pv. syringae. Xanthomonas arboricola $\cdot$ Biolog GEN III MicroPlate . Phenotypic characterization $\cdot 16 \mathrm{~S}$ rRNA $\cdot g y r B \cdot r p o B$

\section{Introduction}

In recent years, there has been an increase in interest in viticulture in Poland. Currently, the area of vineyards is estimated at over 400 ha and is still growing. Among the diseases attacking grapevine (Vitis vinifera), powdery mildew (Uncinula necator), downy mildew (Plasmopara viticola) and grey mold (Botrytis cinerea) are considered the most important. In some countries, there are quarantine diseases: bacterial blight of grapevine and Pierce's disease of grapevine caused by Xylophilus ampelinus and Xylella fastidiosa, respectively (Janse and Obradovic 2010). Reduction in the productivity of grapevines can also be caused by the bacteria: Pseudomonas syringae (pathovar undefined) (bark necrosis and leaf spot), (Klinger et al. 1976; Cugusi et al. 1986; Hall et al. 2002); Pseudomonas syringae pv. syringae (Pss) (bacterial inflorescence rot, bacterial leaf spot, angular leaf lesions and grapevine bunch rot); (Whitelaw-Weckert et al. 2011; Hall et al. 2016, Porotikova et al. 2017; Gerin et al. 2019), and Xanthomonas campestris pv. viticola (leaf spot and bacterial canker) (Chand and Kishun 1990; Lima et al. 1999; Neto et al. 2011). Due to the unclear taxonomic position of the last of these pathogens, Gama et al. (2018), based on extensive molecular studies, proposed its reposition on Xanthomonas citri pv. viticola. Ferreira 
et al. (2019) analyzing sequences of seven housekeeping genes confirmed the taxonomic status of strains pathogenic on grapevine and Amaranthus as members of $X$. citri pv. viticola and found that it is a well-defined monophyletic pathovar.

Surveys carried out in late spring and the beginning of summer in 2009 and 2011 on a grapevine plantation of cvs. Fanny and Muscat Bleu in Central Poland showed occurrence of dark brown, necrotic spots on the leaves and shoots. On the leaves, their shape was at first circular, but when degradation of the tissue between vascular bundles progressed, the necroses became angular. In some cases, they were irregular and covered quite large areas of the leaf blades. Whilst initially moist, they dried out over time. A characteristic yellow halo was observed around some spots. On shoots, in addition to superficial small necrotic spots, the other spots were elongated in shape and sometimes covered a large area (Fig. 1). These symptoms were similar to those described in the literature for Pseudomonas syringae pv. syringae (Whitelaw-Weckert et al. 2011; Hall et al. 2019; Porotikova et al. 2017) and $X$. citri pv. viticola (Chand and Kishun 1990; Jambenal 2008; Jambenal et al. 2011).

The first report of $P$. syringae as a grapevine pathogen came from Argentina (Klingner et al. 1976). The symptoms were described as necrotic lesions on the leaf blades, petioles, rachis, tendrils and branches. In Sardinia, the main symptoms induced by this pathogen were related to the decay of grapevine wood and bark (Cugusi et al. 1986). The disease in the latter case, caused damage to the bark around the circumference of the trunk, which led to plant death. P. syringae was also was identified as the cause of angular leaf lesions of grapes growing on plantations in South Australia, which occasionally coalesced and caused chlorosis and senescence of the infected leaves (Hall et al. 2002). The disease was observed only on leaves, and no apparent effect on fruit set and yield was confirmed. However, in later years, Whitelaw-Weckert et al. (2011) isolated Pss also from shrivelled berries and necrotic inflorescences of grapevine. The disease severity was very high and significantly reduced the yield. Recently, bacterial leaf spot caused by Pss was detected on the Kerch peninsula, Crimea. (Porotikova et al. 2017). Berry rot caused by this pathogen was also found in several vineyards in Apulia, southern Italy (Gerin et al. 2019).

Necrotic spots on the leaves and shoots of grapevines as well as stem cankers are also caused by the bacterium
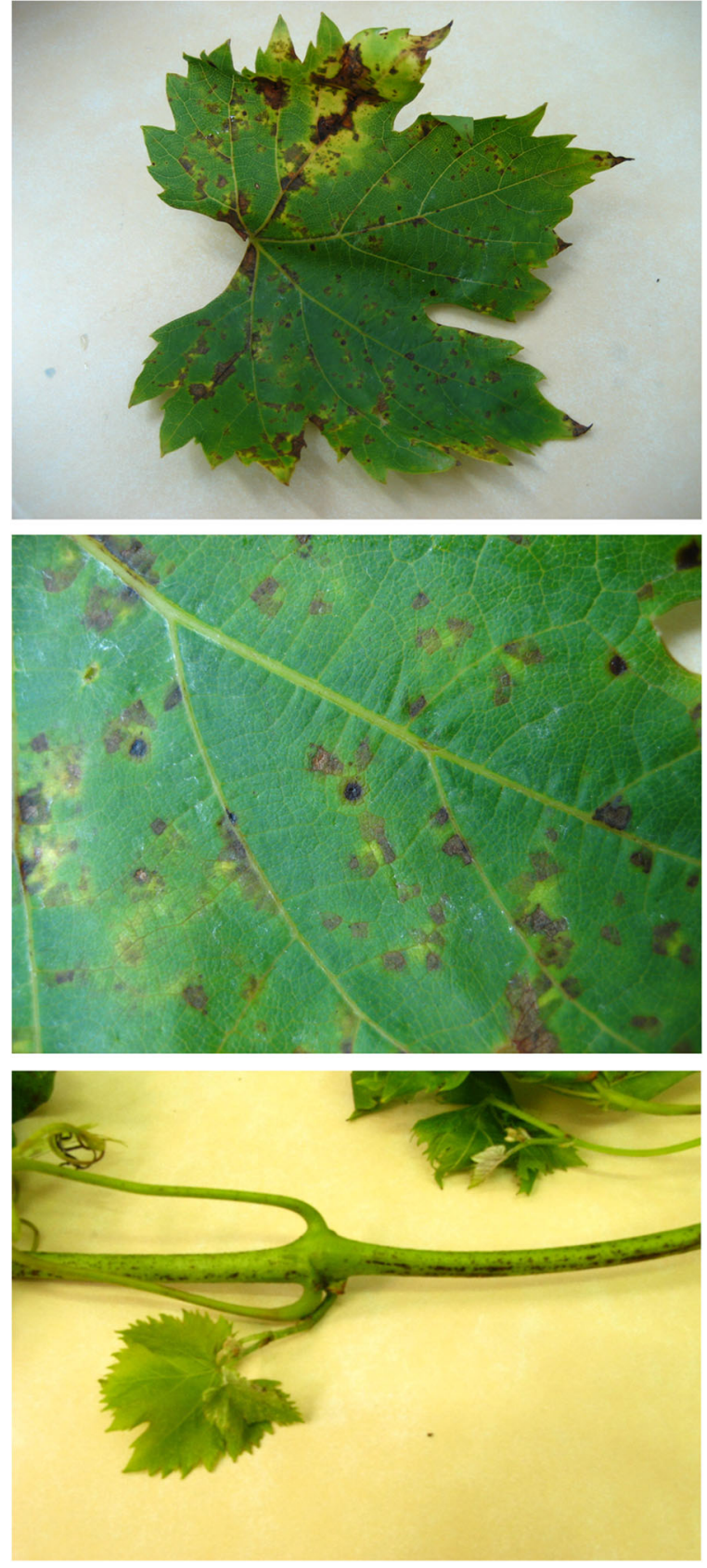

Fig. 1 Symptoms of bacterial necrotic spots on grapevine leaves and canes cv. Fanny, natural infection

$X$. citri pv. viticola. The disease was described for the first time in India by Nayudu (1972); however, this report incorrectly identified its causal agent as Pseudomonas viticola. Later, Dye (1978) redefined its taxonomic position and named it $X$. campestris pv. viticola. Chand and Kishun (1990) also reported the epidemic occurrence of this disease in India and the extensive 
losses in yield it caused. The disease was described as small water-soaked lesions surrounded by a yellow halo on the lower surface of the leaf. The lesions enlarge, become angular, sometimes coalesce and form large patches on petioles and canes. On the berries, the lesions were brown or black. The pathogen is thought to have been transferred from India to Brazil with plant propagation material, where it was discovered for the first time in 1998, (Neto et al. 2011). At present, the disease is considered one of the most important factors limiting vineyard production in the northeastern region of this country, and its causal agent is classified as a quarantine organism (Tostes et al. 2014, Guerra et al. 2018). X. citri pv. viticola have been isolated from asymptomatic grapevine seeds and berries, which suggests systemic colonization of different tissues and indicates an important niche for the survival and dissemination of this pathogen (Tostes et al. 2014).

The aim of our study was to elucidate the bacterial etiology of necrotic spots on the leaves and shoots of grapevine cvs. Fanny and Muscat Bleu found in a vineyard located in Central Poland. The analysis included isolation of suspected pathogens on microbiological media, their identification using conventional and molecular methods and determination of their pathogenicity to fulfil Koch's postulates.

\section{Material and methods}

Bacteria isolation from symptomatic tissue

Leaf and young shoot samples, with dark brown, necrotic spots as described above were collected from the grapevines cvs. Fanny and Muscat Bleu. Tissues were first disinfected by wiping with soft cotton soaked with $50 \%$ ethanol. After drying, 2-5 pieces of 3-5 $\mathrm{mm}$ in diameter per sample were aseptically excised from the border between necrotic and apparently healthy tissue and placed into 1-2 $\mathrm{ml}$ of sterile distilled water (SDW) in a Petri dish. Next, they were chopped with a sterile scalpel, and after $30 \mathrm{~min}$ the obtained suspension was streaked on NAS medium (2.3\% Difco Nutrient Agar with $5 \%$ sucrose in SDW). During incubation at $26^{\circ} \mathrm{C}$ for 5 days, the morphology of growing bacterial colonies was observed. Colonies showing a typical pseudomonad and xanthomonad morphology were subjected to further study. For comparison, the reference strains: Pseudomonas syringae pv. syringae $\mathrm{LMG}^{247^{\mathrm{T}}}$,
Xanthomonas campestris pv. campestris 0222 XccTor (Mikiciński et al. 2010), X. c. pv. viticola $\mathrm{LMG} 965^{\mathrm{PT}}$ and $X$. arboricola CFBP $2528^{\mathrm{T}}$ were included.

Pathogenicity assays

The obtained isolates and reference strains were tested for their ability to induce a hypersensitive reaction (HR) on leaves of tobacco cv. Samsun according to the method of Klement (1963). Aqueous bacterial suspensions of $10^{7}$ and $10^{9} \mathrm{cfu} / \mathrm{ml}^{-1}$ prepared from a culture of each isolate cultivated on King's B medium (3.8\% Difco Pseudomonas-Agar F, $1 \%$ glycerol) was injected into the mesophyll of fully expanded tobacco leaves using a hypodermic syringe. Induction of HR was observed within 24-48 h.

Isolates inducing $\mathrm{HR}$ on tobacco and reference strains were subjected to tests for pectolytic activity on potato tuber slices and/or crystal violet pectate (CVP) medium. After washing in tap water, potato tubers were disinfected by dipping for $5 \mathrm{~min}$ into $70 \%$ ethanol and then washing several times in SDW. The $10 \mathrm{~mm}$-thick slices were placed on wet filter paper in Petri dishes. Two loops of bacterial culture grown for $24 \mathrm{~h}$ on NAS medium were transferred to their upper surfaces and equally distributed. After $24-48 \mathrm{~h}$ of incubation at $25{ }^{\circ} \mathrm{C}$, observations of rot development were made. Tests on CVP medium $(0.2 \%$ crystal violet, $1.36 \%$ $\mathrm{CaCl}_{2}, 0.2 \% \mathrm{NaNO}_{3}, 0.5 \%$ sodium citrate, $0.1 \%$ tryptone, $1.8 \%$ polygalacturonic acid and $0.8 \%$ agar in SDW) were performed according to Cuppels and Kelman (1974). A water diluted bacterial suspension of each isolate and reference strains LMG $1247^{\mathrm{T}}$ and 0222 XccTor was uniformly distributed with the glass rod on the medium. The presence of characteristic pits around colonies after $3-4$ days of incubation at $27{ }^{\circ} \mathrm{C}$ was considered to indicate pectolytic activity.

Seven isolates inducing HR, including two showing also pectolytic activity, were selected for pathogenicity test and all next studies regarding their identification. Young leaves of grapevine cv. Fanny were cut at the base of the petiole, disinfected by wiping with soft cotton soaked with $50 \%$ ethanol, rinsed several times in SDW and placed on wet filter paper in sterile Petri dishes (20 cm diameter). A drop of $10 \mu \mathrm{l}$ of an aqueous suspension of each isolate, containing $10^{7} \mathrm{cfu}$, was placed on a upper leaf surface of which epidermis was spot-wounded with entomological needle. Three leaves at 4-6 
points on each were inoculated with each isolate. Observations of lesion development were made within 10 days of incubation at $26{ }^{\circ} \mathrm{C}$. From the necrotic tissue that was formed around the inoculation sites, re-isolations of bacteria were made. The identity of the inoculated bacteria was confirmed on the basis of colony morphology and PCR with primers X1 and X2 (Maes 1993) and primers for syrB and $\operatorname{syr} D$ genes (Sorensen et al. 1998; Bultreys and Gheysen, 1999).

\section{Identification of selected isolates}

\section{Phenotypic characterization}

The following tests, selected according to the keys of Bradbury (1988), Lelliott and Stead (1987), Schaad et al. (2001) and Kałużna et al. (2012) were performed: colony morphology on NAS medium; Gram reaction (classical staining and 3\% $\mathrm{KOH}$ test), spore formation (heat test), presence of oxidase, motility, oxidative/ fermentative metabolism of glucose, nitrate reduction to nitrite, presence of catalase, production of fluorescent pigment, levan production from sucrose, production of dihydrolase of arginine, hydrolysis of gelatine, starch and esculin, acid production from glucose. All seven isolates and reference strains LMG $1247^{\mathrm{T}}$ and 0222 XccTor were tested at least twice. Additionally, all these isolates and reference strains LMG $1247^{\mathrm{T}}$, LMG $965^{\mathrm{PT}}$ CFBP $2528^{\mathrm{T}}$ were identified using the Biolog GEN III test plates (BIOLOG, Hayward, CA, USA). The bacteria were cultivated on the BUG medium (Biolog Universal Growth medium) at $33{ }^{\circ} \mathrm{C}$ for $48 \mathrm{~h}$ and the colonies formed were used for the preparation of bacterial suspension for inoculation of the test plates. The inoculated GENIII plates were incubated at $30{ }^{\circ} \mathrm{C}$ for $48 \mathrm{~h}$. The results were read every $24 \mathrm{~h}$ with the use of Microplate reader ELx 808 (Biotek). The phenotypic profiles were interpreted by the Microlog3 software (version 5.2.2 b35), equipped with a database for GENIII (version 2.8).

Data after $48 \mathrm{~h}$ incubation of GENIII plates were used with MEGA X software (version 10.1.6) for building the UPGMA phenogram. Three variables, i.e. positive reaction, negative reaction and borderline reaction, were used according to the strain characteristics from the Biolog system for preparing the data for MEGA X software.

\section{DNA-based analysis}

Genomic DNA of all seven isolates was isolated according to the method of Aljanabi and Martinez (1997) with the modification described by Kałużna et al. (2012).

Isolates with yellow colonies were tested using PCR with the primers $\mathrm{X} 1$ and $\mathrm{X} 2$ specific for the Xanthomonas genus according to the method described by Maes (1993). For these isolates 16S rRNA sequencing was also performed using fD1 and rP2 primers (Weisburg et al. 1991). The sequences obtained were compared to those available in NCBI GenBank (http://www.ncbi.nlm.nih.gov) using the BlastN program to find the closest relatives and the EzTaxon server to find the closest relatives (Yoon et al. 2017). Additionally, a fragment of the $g y r B$ gene was amplified with primers XgyrPCR2F and Xgyrrsp1 and sequenced (Parkinson et al. 2007). The obtained sequences were subjected to phylogenetic analysis along with bacteria belonging to the Xanthomonas genus, and seven $X$. arboricola pathotype strains, available in GenBank. Maximum likelihood trees were generated with the MEGA 5 software package (Tamura et al. 2011) using the Tamura-Nei evolutionary model with gamma distribution (found as the best substitution model) and 1000 bootstrap replicates. The Xanthomonas isolates were also subjected to real-time PCR with primers Xcv18f and Xcv19r according to conditions described by Villela et al. (2019) specific for $X$. citri pv. viticola. The reaction was conducted in a Bio-Rad CFX96 thermocycler with SsoAdvanced SYBR Green Supermix (Bio-Rad, Hercules, CA). As a positive control, X. c. pv. viticola strain LMG $965^{\mathrm{PT}}$ was included.

For fluorescent isolates, analysis of the partial sequences of two housekeeping genes, gyr $B$ and $r p o B$, was performed. Amplifications were performed with the primers gyrB-F and gyrB-R (Sarkar and Guttman 2004) and LAPS and LAPS27 for the rpoB gene (Ait Tayeb et al. 2005) with PCR conditions as described in the original papers with changes of reagents i.e. Dream Taq Green polymerase was used instead of Taq DNA polymerase (Invitrogen, Cergy Pontoise, France), for primers LAPS and MBI-Fermentas Taq polymerase for primers gyrB-F and gyrB-R (Thermo Scientific, Vilnius, Lithuania). The sequences obtained were assembled into contigs using the SeqMan Lasergene package (DNASTAR, Inc., Madison, WI) and compared with sequences deposited in NCBI GenBank (http://www. ncbi.nlm.nih.gov). For phylogenetic analysis of these 
isolates and reference strain $\mathrm{LMG} 1247^{\mathrm{T}}$, the sequences of gyr $B$ and $r p o B$ of the type strains of other species of Pseudomonas obtained from GenBank (their accession numbers are given on the phylogenetic trees) were used.

Maximum likelihood phylogenetic trees were constructed with the MEGA X program (Kumar et al. 2018). The dendrograms based on sequence analysis of gyr $B$ and $r p o B$ for grapevine isolates and all type strains of Pseudomonas species were constructed using the general time reversible evolutionary model with gamma distribution and by assuming that a certain fraction of sites are evolutionarily invariable $(\mathrm{G}+\mathrm{I})$ (found as the best substitution model was automatically determined in MEGA $\mathrm{X}$ program after calculation and analyses of all sequences of the target gene submitted) (Nei and Kumar 2000). The dendrogram, however, for all grapevine isolates and the closest relatives was constructed using the Tamura-Nei model with gamma distribution and by assuming that a certain fraction of sites are evolutionarily invariable $(G+I)$ found as the best substitution model was automatically determined in MEGA X program after calculation and analyses of on all sequence of the target gene submitted) (Nei and Kumar 2000). The significance of the internal branches of all dendrograms constructed was estimated with bootstrap values expressed as percentages of 500 replications.

\section{Syringomycin production}

Because sequence analysis of housekeeping genes showed that the Pseudomonas isolates had the highest similarity to P. syringae pv. syringae reference strain $\mathrm{LMG} 1247^{\mathrm{T}}$, presence of genes encoding syringomycin the toxin producing by majority of PSS strain was determined. To detect the genes responsible for toxin production, two separate PCRs with the primer pairs syrB1/syrB2 and syrD1/syrD2 were performed to amplify the $s y r B$ and $s y r D$ genes, respectively (Sorensen et al. 1998; Bultreys and Gheysen 1999).
Amplifications were conducted according to the conditions presented in the original papers with small modifications of annealing temperature for $\operatorname{syr} B$ as described in Kałużna et al. (2010).

\section{Results and discussion}

From 35 symptomatic leaf and shoot samples, 70 bacterial isolates were obtained. Sixteen of them induced visible HR on tobacco leaves (both at $10^{7}$ and $10^{9} \mathrm{CFU} /$ $\mathrm{ml}^{-1}$ ) after 18-24 h, but only two of them showed pectolytic activity. These isolates caused rot, which penetrated the entire potato tuber slices within 24$48 \mathrm{~h}$, and pits around bacterial colonies on CVP medium within 3-4 days after plating. Similar reactions were observed after using reference strain 0222 XccTor but not $P$. syringae $\mathrm{pv}$. syringae $\mathrm{LMG} 1247^{\mathrm{T}}$. Also reference strains $X$. c. pv. viticola LMG 965 and $X$. arboricola CFBP $2528^{\mathrm{T}}$ did not cause potato rot. For detailed study, five isolates (WA1B, WA1D, WA1A, - originating from young shoots and WA29, WA30 - originating from leaves) were selected from the group giving an HRpositive reaction only, and those two (WA2B, WA2C originating from young shoots) showing both positive HR and pectolytic activity. As a result of inoculation of grapevine leaves cv. Fanny, all seven isolates caused necrotic, water-soaked spots around the inoculation site that were clearly visible after twenty-four hours. Over the next 2 days, the size of the necrosis increased to $10 \mathrm{~mm}$ or more in diameter (Fig. 2) - and after next 4 days (7 days from inoculation) they only slightly enlarged and the tissue began to dry out. The observations made over the next three days showed no significant increase of necrosis. In the control (treatment with sterile water), the colour of the tissue around the wounds at the beginning did not change, and later, very small
Fig. 2 Necrotic spots on grapevine leaves cv. Fanny, 5 days after artificial inoculation with: from left isolate $2 \mathrm{C}$ and right isolate $12 \mathrm{~A}$
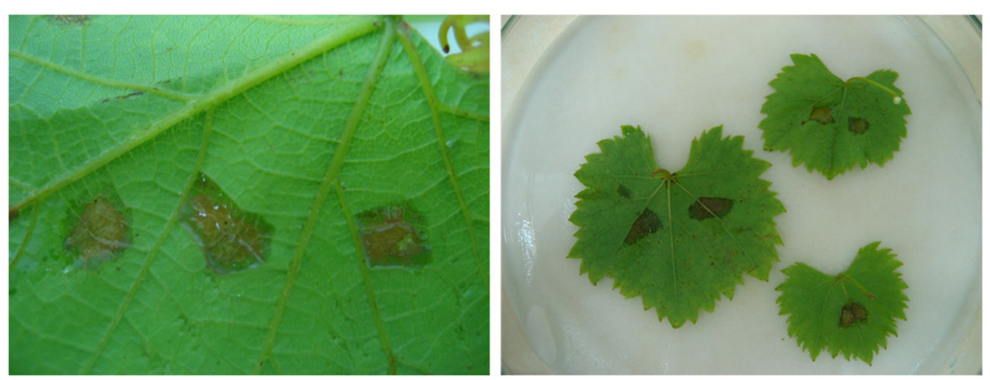
brown discolorations $(\sim 1 \mathrm{~mm})$ were observed. Reisolations of bacteria from the margins of the randomly selected necrotic spots on NAS medium (15 in total) resulted in colonies with an identical morphology to those used for inoculation. The identity of re-isolates was further confirmed by PCR with primers X1 and X2 (Maes 1993) and primers for $s y r B$ and $s y r D$ genes (Sorensen et al. 1998; Bultreys and Gheysen 1999).

All seven isolates were Gram-negative, motile, nonspore-forming rods (Table 1). They did not produce oxidase, with the exception of the isolate WA2B, which gave a weak positive reaction, did not reduce nitrate to nitrite and did not produce arginine dihydrolase, but produced catalase, levan, acid from glucose and showed oxidative metabolism of glucose and the ability to hydrolyse both gelatine and esculin (Table 1). Based on other characteristics, the isolates were divided into two groups. Group I included two isolates (WA2B and WA2C) forming yellow colonies on King's B and
NAS media, not producing fluorescent pigment on King's B medium, and possessing the ability to hydrolyse starch (Table 1). They showed the same features as the strain $X$. campestris pv. campestris 0222 XccTor, which was used as a reference for this group. Group II consisted of five isolates (WA1B, WA1D, WA12A, WA29, WA30) forming greyish-white colonies, producing fluorescent pigment on King's B medium, not hydrolysing starch, and not showing pectolytic abilities on either potato tuber slices or CVP medium. The characteristics of the isolates from this group were identical to those of the reference strain $P$. syringae pv. syringae (Pss) $\mathrm{LMG} 1247^{\mathrm{T}}$ used for this group (Table 1).

Identification of the isolates WA2B and WA2C using conventional methods allowed them to be classified into the genus Xanthomonas (Table 1). The phenotypic characteristics of both strains were generally similar with respect to the studied morphological, physiological and biochemical features to strains isolated from spotted

Table 1 Phenotypic features of bacteria isolated from leaves and young shoots of grapevine

\begin{tabular}{|c|c|c|c|c|c|c|c|c|c|}
\hline \multirow[t]{2}{*}{ Character } & \multicolumn{3}{|l|}{ Group I } & \multicolumn{6}{|c|}{ Group II } \\
\hline & WA2B & WA2C & 0222 XccTor* & WA1B & WA1D & WA12A & WA29 & WA30 & $\begin{array}{l}\mathrm{LMG} \\
1247^{T^{*}}\end{array}$ \\
\hline Colony color on King's B and NAS & $\mathrm{y}^{* *}$ & $\mathrm{y}$ & $\mathrm{y}$ & $\mathrm{g}-\mathrm{w}^{* *}$ & g-w & g-w & g-w & $\mathrm{g}-\mathrm{w}$ & g-w \\
\hline \multirow[t]{2}{*}{ Gram stain Reaction with $3 \% \mathrm{KOH}^{* * *}$} & - & - & - & - & - & - & - & - & - \\
\hline & + & + & + & + & + & + & + & + & + \\
\hline Spore formation & - & - & - & - & - & - & - & - & - \\
\hline Motility & + & + & + & + & + & + & + & + & + \\
\hline Fluorescence & - & - & - & + & + & + & + & + & + \\
\hline Oxidase & \pm & - & - & - & - & - & - & - & - \\
\hline Catalase & + & + & + & + & + & + & + & + & + \\
\hline Metabolism of glucose $(\mathrm{O} / \mathrm{F})$ & $\mathrm{O}$ & $\mathrm{O}$ & $\mathrm{O}$ & $\mathrm{O}$ & $\mathrm{O}$ & $\mathrm{O}$ & $\mathrm{O}$ & $\mathrm{O}$ & $\mathrm{O}$ \\
\hline Levan & + & + & + & + & + & + & + & + & + \\
\hline Hydrolysis of: & + & + & + & + & + & + & + & + & + \\
\hline Gelatine & + & + & + & - & - & - & - & - & - \\
\hline $\begin{array}{l}\text { Starch } \\
\text { Esculin }\end{array}$ & ++ & ++ & ++ & + & + & + & + & + & + \\
\hline Nitrate reduction & - & - & - & - & - & - & - & - & - \\
\hline Arginine dihydrolase & - & - & - & - & - & - & - & - & - \\
\hline Acid prodution from glucose & + & + & + & + & + & + & + & + & + \\
\hline HR on tobacco leaves & + & + & + & + & + & + & + & + & + \\
\hline Ability to macerate potato & ++ & ++ & + & - & - & - & - & - & - \\
\hline Pectolytic activity on CVP & + & + & + & - & - & - & - & - & - \\
\hline
\end{tabular}

*reference strain; **y- yellow, g-w grey-white colony on NAS and King's B media; presence (+) or lack (-) of studied feature; O/F oxidative-fermentative metabolism

*** $\mathrm{KOH}$ positive, meaning a Gram-negative bacterium 
grapevine leaves by Chand and Kishun (1990) in India and by Lima et al. (1999) in Brazil and identified as X. citri pv. viticola. However, they differed in the colour of the bacterial colony (which in case of $X$. citri pv. viticola was white on nutrient agar media), pectolytic ability and HR. It should be noted that a study by Jambenal (2008) and Jambenal et al. (2011) indicated that the grapevine strain identified as $X$. citri pv. viticola produced light yellow colonies and a typical hypersensitive reaction on tobacco cv. Samsun within $24 \mathrm{~h}$ of inoculation. Lima et al. (1999) found that strains of $X$. citri pv. viticola were HR negative or weakly positive after $24 \mathrm{~h}$ (plants showed yellowing after $48 \mathrm{~h}$ and necrosis after three days). Similar results were obtained in our study in case of the reference strain LMG $965^{\mathrm{PT}}$ but strain CFBP $2528^{\mathrm{T}}$ induced normal HR on tobacco.

Using Biolog GEN III MicroPlate tests we showed that isolates WA1B, WA1D, WA12A, WA29, WA30 belong to the species of Pseudomonas syringae while WA2B and WA2C to Xanthomonas arboricola (Fig. 3, Table S1). The groups of isolates clustered with the reference strains P. syringae pv. syringae $\mathrm{LMG} 1247^{\mathrm{T}}$ and $X$. arboricola CFBP $2528^{\mathrm{T}}$, respectively. On the other hand, the reference strain LMG $965^{\mathrm{PT}}$ of $X$. citri $p v$. viticola was identified as Xanthomonas perforans. This supports the method limitations in bacteria identification (Adriko et al. 2016, PrietoCalvo et al. 2016) as also emerged from the recent work of Woźniak et al. (2019) that, comparing identification of endophytic bacteria isolates using Biolog GEN III plates and 16S rRNA gene sequences, pointed out that a degree of uncertainty especially in case of the metabolically lessactive isolates.

The affinity of isolates WA2B and WA2C to Xanthomonas spp. was confirmed by PCR with primers $\mathrm{X} 1$ and X2 specific for this genus and analysis of the $16 \mathrm{~S}$ rRNA gene sequence. The 1411 nucleotide-long fragments of the $16 \mathrm{~S}$ rDNA sequence in both strains were identical one to each other and to the $16 \mathrm{~S}$ rDNA sequences of type strains of three Xanthomonas species: X. campestris ATCC $33913^{\mathrm{T}}$, X. cucurbitae LMG $690^{\mathrm{T}}$ and $X$. cynarae CFBP $4188^{\mathrm{T}}$ and differed at one position from the sequences of $X$. arboricola $\mathrm{LMG} 747^{\mathrm{T}}$ and $X$. hortorum LMG $733^{\mathrm{T}}$. However, phylogenetic analysis based on sequences of a fragment of the $\operatorname{gyr} B$ gene showed that both isolates were grouped with strains belonging to the species $X$. arboricola (Fig. 4). $X$. arboricola was established after reclassification of the Xanthomonas genus based on comprehensive bacterial DNA-DNA hybridization study (Vauterin et al.

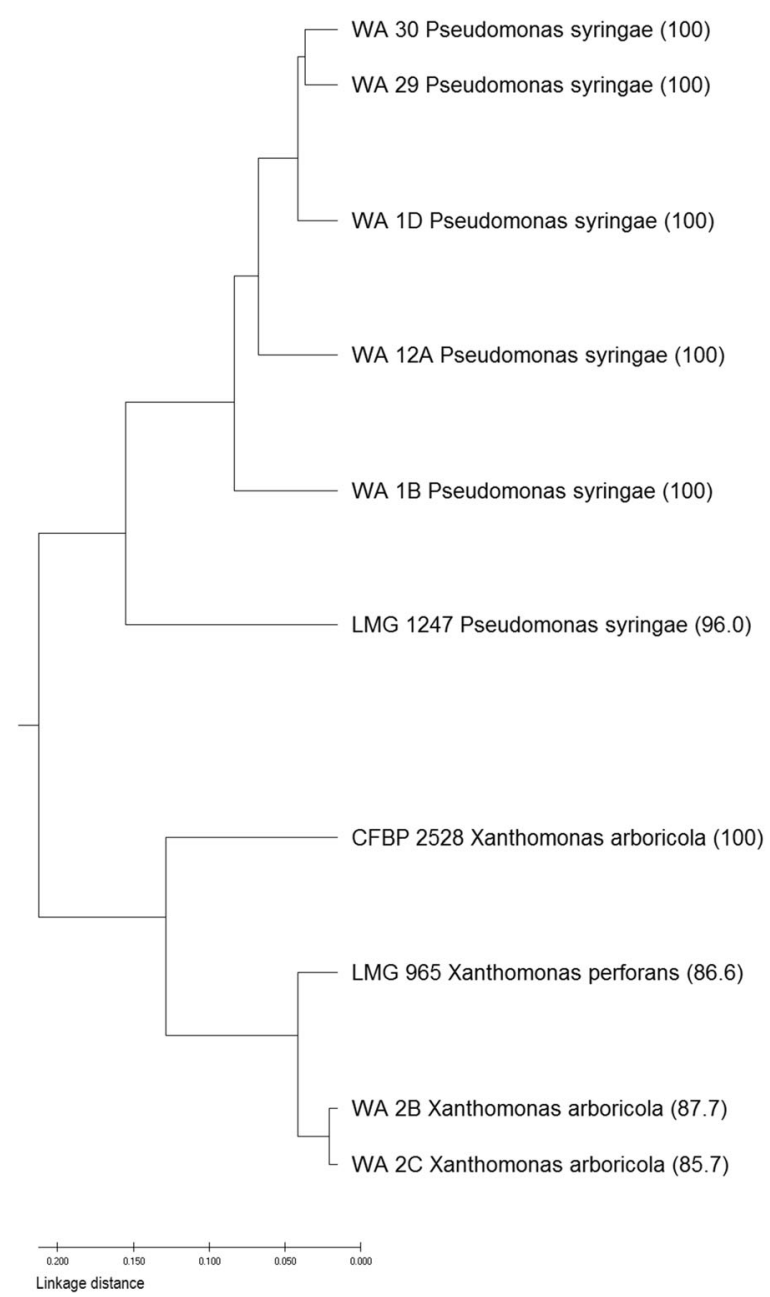

Fig. 3 Phenogram showing the relationships among studied isolates and reference strains based on Biolog system GEN III test plates (BIOLOGY, Hayward, CA, USA) using the UPGMA method

1995). It is divided into pathovars, some of which are causal agents of disease in nut and stone fruit trees. Janse et al. (2001) isolated a new pathovar of $X$. arboricola from strawberry leaves in Northern Italy that was named pv. fragariae. It differs from another longer known pathogen of strawberry, namely, X. fragariae, which causes angular leaf spot of strawberry. Many phenotypic characteristics of strains WA2B and WA2C are similar to those of $X$. arboricola pv. fragariae. Particularly noteworthy is the ability to cause soft rot of potato and tobacco hypersensitivity. Also based on the $\operatorname{gyr} B$ sequence phylogenetic analysis the studied isolates were more similar to $X$. arboricola and quite distantly related to the type species of $X$. citri $\mathrm{LMG} 9322^{\mathrm{T}}$ (Fig. 4). Recent 


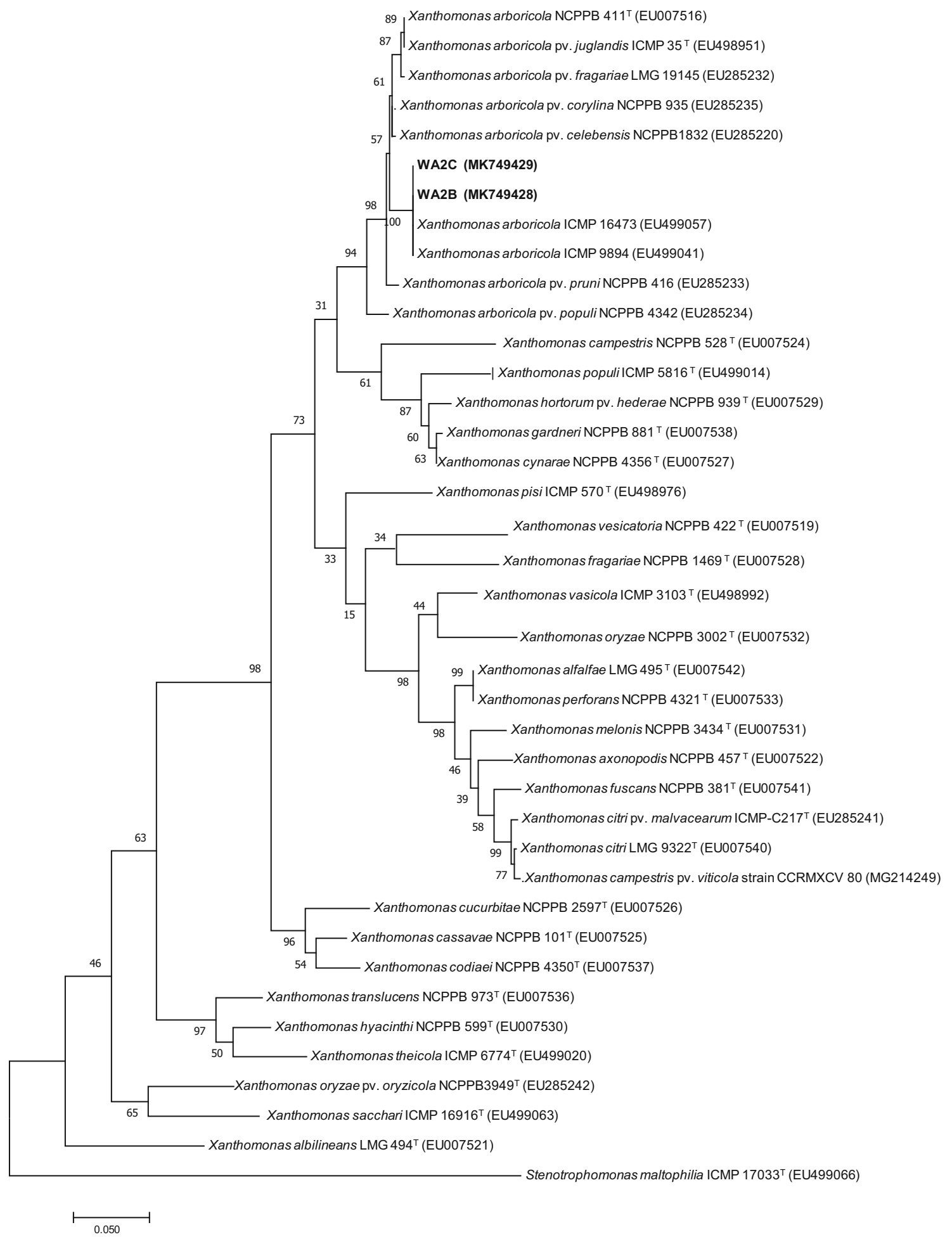


4 Fig. 4 Maximum Likelihood tree of isolates obtained from grapevine and the closest neighbor of other species of Xanthomonas spp., based on the analysis of $g y r B$ gene sequence. Bar estimated nucleotide substitutions per site. Bootstrap values (expressed as percentages of 500 replications) are indicated at each node. As an outgroup, the sequence of $g y r B$ gene of Stenotrophomonas maltophilia ICMP $17033^{\mathrm{T}}$ was used

taxonomic studies of the genus Xanthomonas performed by Fischer-Le et al. 2015 showed that strains isolated from other hosts, formerly classified as $X$. campestris pv. campestris belong in fact to $X$. arboricola, extending the host range of this pathogen. Strains WA2B, WA2C were negative in real-time PCR with primers Xcv18f and Xcv19r specific for $X$. citri pv. viticola while reference strain LMG 965 gave a positive signal.
As mentioned above the phenotypic characteristics of Group II isolates indicate their affinity to the species Pseudomonas syringae (Table 1) and were the same as those of strains isolated from rotted grapevine inflorescences in Australia, which were classified as $P$. syringae pv. syringae (PSs) (Hall et al. 2016).

The constructed dendrograms based on sequence analyses of the gyrB and $r p o B$ genes (Fig.5, Fig. S1, Fig. S2), including grapevine isolates and all type strains of genus Pseudomonas, showed that the studied isolates were most closely related to Pseudomonas syringae PDDCC $3023^{\mathrm{T}}$ which is the type strain of the species but also the pathotype od P.s. pv. syringae isolated from Syringa vulgaris in the UK in 1950 and to Pseudomonas congelans $\mathrm{LMG} 21466^{\mathrm{T}}$, derived from the phyllosphere

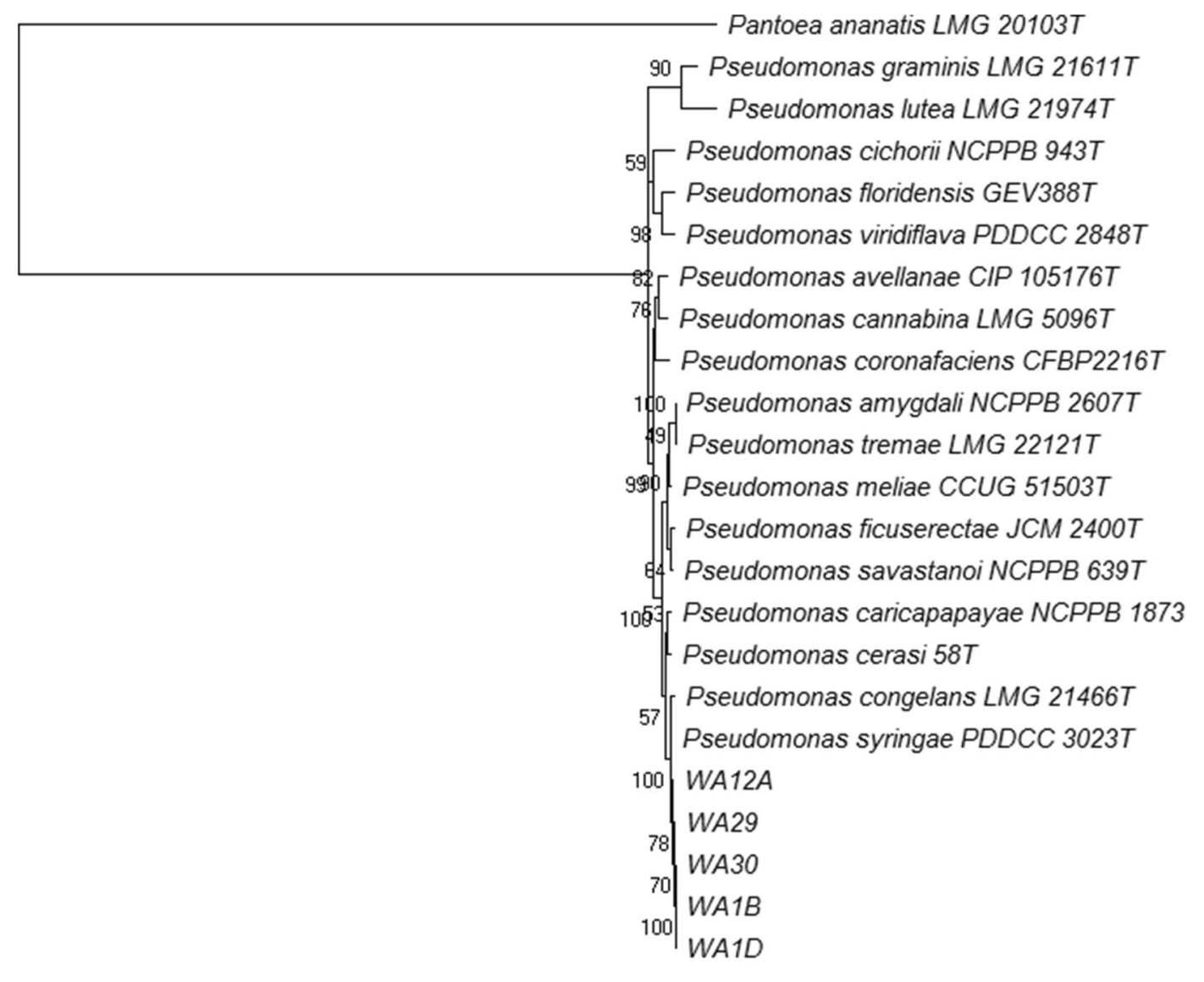

0.50

Fig. 5 Maximum likelihood tree indicating the phylogenetic position of isolates obtained from grapevine and the closest neighbor of other species of Pseudomonas spp., based on the analysis of the concatenated data set of partial sequences of $g y r B$ and $r p o B$ genes.

Bar 0.50 estimated nucleotide substitutions per site. Bootstrap values (expressed as percentages of 500 replications) are indicated at each node. As an outgroup, the sequence of the same genes of Pantoea ananatis LMG $20103^{T}$ was used 
of grasses in Paulinenaue, Brandenburg, Germany, and isolated in 1994. Both species are members of the socalled $P$. syringae group proposed by Anzai et al. (2000), comprising 9 other closely related species but at present including more validly described species (List of Prokaryotic Names with Standing in Nomenclature; LPSN; Parte, 2014) for which the present taxonomic status is more expanded/extensive based on the recently described results phylogenomic analysis (Berge et al. 2014, Kałużna et al. 2016, Gomila et al. 2017) and also were placed in the same main clade 1 on phylogenomic tree in the study of Tran et al. (2017).

Specific amplification products of fragments of the syrB and $s y r D$ genes involved in the synthesis and secretion of syringomycin (Quigley et al. 1993; Zhang et al. 1995; Bender et al. 1999) were present for strains WA1B, WA1D and WA30 and for strains WA1B, WA1D, WA12A, WA30, respectively. Only strain WA29 did not possess these genes. The lack of one or two genes can be explained by their absence or a mutation in the genes that did not allow for their amplification (Ferrante et al. 2015). In contrast to our results, in the studies of Abbasi et al. (2013), Gilbert et al. (2009), and Abdellatif et al. (2017) all PSS strains had the $\operatorname{syr} B$ gene. This gene was also identified in the majority of PsS strains in studies of Scortichini et al. (2003), although (weakly) pathogenic strains from zucchini, magnolia and avocado also lacked the $g y r B$ gene Renick et al. (2008) detected the $s y r D$ gene only in approximately $60 \%$ of pathogenic Pss strains. Mutants not producing syringomycin were also detected among the strains investigated in a study by Sorensen et al. (1998), confirming again that the assessment of syringomycin production capacity should not be used as the most important criterion for the identification of PSS strains. The production of syringomycin is considered to be an important virulence factor of PSS strains, but in the reports of other authors (Sobiczewski 1984; Seemüler and Arnold 1978), there was no correlation among the size of the inhibition zone produced when using the indicator strain Rhodotorula pilimanae MUCL 30397, the presence of one or both of the genes involved in the synthesis of syringomycin and the virulence of the strains tested. Further research, including testing more housekeeping genes will be necessary to define the taxonomic status on pathovar level of strains of Xanthomonas arboricola causing young shoot and cane spot on grapevine in Poland.
Acknowledgements The authors wish to express their thanks for excellent technical help of Mrs. Danuta Rasz-Zając and Mrs. Dominika Niedzielska.

\section{Compliance with ethical standards}

Human and Animal Studies This article does not contain any study with human participants or animals performed by the authors

Conflict of interest The authors have no conflicts of interest to declare.

Open Access This article is licensed under a Creative Commons Attribution 4.0 International License, which permits use, sharing, adaptation, distribution and reproduction in any medium or format, as long as you give appropriate credit to the original author(s) and the source, provide a link to the Creative Commons licence, and indicate if changes were made. The images or other third party material in this article are included in the article's Creative Commons licence, unless indicated otherwise in a credit line to the material. If material is not included in the article's Creative Commons licence and your intended use is not permitted by statutory regulation or exceeds the permitted use, you will need to obtain permission directly from the copyright holder. To view a copy of this licence, visit http://creativecommons.org/licenses/by/4.0/.

\section{References}

Abbasi, V., Rahimian, H., \& Tajick-Ghanbari, M. A. (2013). Genetic variability of Iranian strains of Pseudomonas syringae pv. syringae causing bacterial canker disease of stone fruits. European Journal of Plant Pathology, 135, 225-235.

Abdellatif, E., Kałużna, M., Janse, J. D., Sobiczewski, P., Helali, F., Lamichhane, J. R., \& Rhouma, A. (2017). Phenotypic and genetic characterization of Pseudomonas syringae strains associated with the recent citrus-bacterial blast and bacterial black pit epidemics in Tunisia. Plant Pathology, 66, 10811093.

Adriko, J., Aritua, V., Mortensen, C. N., Tushemereirwe, W. K., Mulondo, A. L., Kubiriba, J., \& Lund, O. S. (2016). Biochemical and molecular tools reveal two diverse Xanthomonas groups in bananas. Microbiological Research, 183, 109-116.

Ait Tayeb, L., Ageron, E., Grimont, F., \& Grimont, P. A. D. (2005). Molecular phylogeny of the genus Pseudomonas based on $r р о B$ sequences and application for the identification of isolates. Research of Microbiolology, 156, 763-773.

Aljanabi, S. M., \& Martinez, I. (1997). Universal and rapid saltextraction of high quality genomic DNA for PCR-based techniques. Nucleic Acids Research, 25, 4692-4693.

Anzai, Y., Kim, H., Park, J.-Y., Wakabayashi, H., \& Oyaizu, H. (2000). Phylogenetic affiliation of the pseudomonads based on 16S rRNA sequence. International Journal of Systematic and Evolutionary Microbiology, 50, 1563-1589. 
Bender, C. L., Alarcón-Chaidez, F., \& Gross, D. C. (1999). Pseudomonas syringae phytotoxins: Mode of action, regulation, and biosynthesis by peptide and polyketide synthetases. Microbiology and Molecular Biology Review, 63, 266-292.

Bradbury, J. F. (1988). Identification of cultivable bacteria from plants and plant tissue cultures by use of simple classical methods. Acta Horticulture, 225, 27-37.

Bultreys, A., \& Gheysen, I. (1999). Biological and molecular detection of toxic lipodepsipeptide-producing Pseudomonas syringae strains and PCR identification in plants. Applied and Environmental Microbiology, 65, 1904-1909.

Chand, R., \& Kishun, R. (1990). Outbreak of grapevine bacterial canker disease in India. Vitis, 29, 183-188.

Cugusi, M., Garau, R., Prota, U., \& Dore, M. (1986). A bark necrosis of grapevine caused by Pseudomonas syringae V. Hall, in Sardinia. Journal of Phytopathology, 116, 176-185.

Cuppels, D., \& Kelman, A. (1974). Evaluation of selective media for isolation of soft rot bacteria from soil and plant tissue. Phytopathology, 64, 468-475.

Dye, D. W. (1978). Genus IX Xanthomonas Dowson 1939. In Young J.M. Dye D.W., Bradbury J.F., Panagopoulos, C.G., Robbs, C.F. 1978: A. proposed nomenclature and classification for plant pathogenic bacteria. New Zealand Journal of Agricultural Research, 21, 563-582.

Ferrante, P., Takikawa, Y., \& Scortichini, M. (2015). Pseudomonas syringae pv. actinidiae strains isolated from past and current epidemics to Actinidia spp. reveal a diverse population structure of the pathogen. European Journal of Plant Pathology, 142(4), 677-689.

Ferreira M.A.S., Bonneau S., Briand M., Cesbron S., Portier P., Darrasse A., Gama M.A.S., Barbosa M.A.G., Mariano R.L.R., Souza E.B. \& Jacques M.A. (2019). Xanthomonas citri pv. viticola affecting grapevine in Brazil: emergence of a successful monomorphic pathogen. Frontiers in Plant Science, 10, 489, doi:https://doi.org/10.3389 /fpls.2019.00489, <i>Xanthomonas citri</i> pv. $<\mathrm{i}>$ viticola $<$ i $>$ Affecting Grapevine in Brazil: Emergence of a Successful Monomorphic Pathogen.

Fischer-Le, S. M., Bonneau, S., Manceau, C., \& Jacques, M.-A. (2015). Aggressive emerging pathovars of Xanthomonas arboricola represent wide spread epidemic clones from poorly pathogenic strains as revealed by multilocus sequence typing. Applied Environmental Microbiology, 81(14), 4651-4668.

Gama M.A.S., Mariano R.L.R., Silva W.J. Jr, Farias A.R.G., Barbosa M.A.G., Ferreira M.A.S. V., Costa C.R.L Jr., Santos L.A. \& Souza E.B. (2018). Taxonomic repositioning of Xanthomonas campestris pv. viticola (Nayudu 1972) Dye 1978 as Xanthomonas citri pv. viticola (Nayudu 1972 Dye 1978 comb. Noc. And emendation of the description of Xanthomonas citri pv. anacardii to include pigmented isolates pathogenic to cashew plant. Phytopathology 108, 10, 1143-1153.

Gerin D., Caridi C., Miccolis A. de, Rotolo C., Dongiovanni C., Faretra F. \& Pallastro S. 2019. First report of Pseudomonas grapevine bunch rot caused by Pseudomonas syringae pv. syringae. https://doi.org/10.1094/PDIS-11-18-1992-RE.

Gilbert, V., Legros, F., Maraite, H., \& Bultreys, A. (2009). Genetic analyses of Pseudomonas syringae isolates from Belgian fruit orchards reveal genetic variability and isolate-host relationships within the pathovar syringae, and help identify both races of the pathovar morsprunorum. European Journal of Plant Pathology, 124, 199-218.

Gomila M., Busquets A., Mulet M., García-Valdés E., Lalucat J. (2017). Clarification of taxonomic status within the Pseudomonas syringae species group based on a phylogenomic analysis. Frontiers in Microbiology, 07 December 2017 | https://doi.org/10.3389/fmicb.2017.02422

Guerra, M. L., Malafaia, C. B., Macedo, A. J., Silva, M. V., Mariano, R. L. R., \& Souza, E. B. (2018). Biofilm formation by Xanthomonas campestris pv. viticola affected by abiotic surfaces and culture media. Tropical Plant Pathology, 43, 146-151.

Hall, B. H., McMahon, R. L., Noble, D., Cother, E. J., \& McLintock, D. (2002). First report of Pseudomonas syringae on grapevines (Vitis vinifera) in South Australia. Australasian Plant Pathology, 31, 421-422.

Hall, S. J., Dry, I. B., Blanchard, C. L., \& Whitelaw-Weckert, M. A. (2016). Phylogenetic relationships of Pseudomonas syringae pv. syringae isolates associated with bacterial inflorescence rot in grapevine. Plant Disease, 100, 607-616.

Hall, S.J., Dry, I. B., Gopurenko, B. Whitelow-Weckert, M.A. (2019). Pseudomonas syringae pv. syringae for cool climate Australian grapevine vineyerds: new phylogroup PG02f associated with bacterial inflorescence rot. Plant Pathology, 68, 312-322.

Jambenal S., (2008). Studies on bacterial leaf spot of grape caused by Xanthomonas campestris pv. viticola (Nayudu) Dye in northern Karnataka. MSc Thesis, University of Agricultural Sciences, Dharwad, India, $64 \mathrm{p}$.

Jambenal, S., Ravikumar, M. R., \& Jambenal, N. H. (2011). Basic studies on Xanthomonas campestris.Pv. viticola causing bacterial leaf spot of grape and evaluated in-vitro efficacy of different chemicals and bioagents against its growth. International Journal of Plant Protection, 4, 397-401.

Janse, J. D., Rossi, M. P., Gorkink, R. F. J., Derks, J. H. J., Swings, J., Janssens, D., \& Scortichini, M. (2001). Bacterial leaf blight of strawberry (Fragaria ( $x$ ) ananassa) caused by a pathovar of Xanthomonas arboricola, not similar to Xanthomonas fragariae Kennedy \& King. Description of causal organism as Xanthomonas arboricola pv. fragariae (pv. Nov., com. Nov.). Plant Pathology, 50, 653-665.

Janse, J. D., \& Obradovic, A. (2010). Xylella fastidiosa: Its biology, diagnosis, control, and risks. Journal of Plant Pathology, 92, 35-48.

Kałużna, M., Puławska, J., \& Sobiczewski, P. (2010). The use of PCR melting profile for typing of Pseudomonas syringae isolates from stone fruit trees. European Journal of Plant Pathology, 126, 437-443.

Kałużna, M., Janse, J. D., \& Young, J. M. (2012). Detection and identification methods and new tests as used and developed in the framework of COST 873 for bacteria pathogenic to stone fruits and nuts Pseudomonas syringae pathovars. Journal of Plant Pathology, 94, 117-126.

Kałużna, M., Willems, A., Pothier, J. F., Ruinelli, M., Sobiczewski, P., \& Puławska, J. (2016). Pseudomonas cerasi sp. nov. (non griffin, 1911) isolated from diseased tissue of cherry. Systematic and Applied Microbiology, 39, 370-377.

Klement, Z. (1963). Method for rapid detection of the pathogenicity of phytopathogenic Pseudomonas. Nature (Lond.), 199, 299-300. 
Klingner, A. E., Palleroni, N. J., \& Pontis, R. E. (1976). Isolation of Pseudomonas syringae from lesions on Vitis vinifera. Phytopathologische Zeitschrift, 86, 107-116.

Kumar, S., Stecher, G., Li, M., Knyaz, C., \& Tamura, K. (2018). MEGA X: Molecular evolutionary genetics analysis across computing platforms. Molecular Biology and Evolution, 35, $1547-1549$.

Lelliott, R. A., \& Stead, D. E. (1987). Methods for the diagnosis of bacterial diseases of plants. Oxford: UKBritish Scociety of Plant Pathology / Blackwell Scientific Publications.

Lima, M. F., Ferreira, A. S. V., Moreira, W. A., \& Dianese, J. C. (1999). Bacterial canker of grapevine in Brazil. Fitopatologia Brasileira, 24, 440-443.

Maes, M. (1993). Fast classification of plant-associated bacteria in the Xanthomonas genus. FEMS Microbiology Letters, 113, $161-166$

Mikiciński, A., Sobiczewski, P., Sulikowska, M., Puławska, J., \& Treder, J. (2010). Pectolytic bacteria associated with soft rot of calla lily (Zantedeschia spp.) tubers. Journal of Phytopathology, 158(4), 201-209.

Nayudu, M. V. (1972). Pseudomonas viticola sp. nov., incitant of new bacterial disease of grapevine. Journal of Phythopathology, 73, 183-186.

Nei, M., \& Kumar, S. (2000). Molecular evolution and Phylogenetics. NewYork: Oxford University Press.

Neto, J. R., Destefano, S. A. L., Rodrigues, L. M. R., Pelloso, D. S., \& da Crus, O. J. L. (2011). Grapevine bacterial canker in stae of Sao Paulo, Brazil: Detection and eradication. Tropical Plant Pathology, 36(1), 42-44.

Parkinson, N., Aritua, V., Heeney, J., Cowie, C., Bew, J., \& Stead, D. (2007). Phylogenetic analysis of Xanthomonas species by comparison of partial gyrase B gene sequences. International Journal of Systematic and Evolutionary Microbiology, 57, 2881-2887.

Parte, A. C. (2014). LPSN-list of prokaryotic names with standing in nomenclature. Nucleic Acids Research, 42, D613-D616. https://doi.org/10.1093/nar/gkt1111.

Porotikova, E. V., Dmitrenko, U. D., Atapina, E. E., Volkov, Y. A., Risovannaya, V. I., Stranishevskaya, E. P., Gorislavets, S. M., Kamionskaya, A. M., \& Vinogradova, S. V. (2017). First report of bacterial leaf spot caused by Pseudomonas syringae on grapevine (Vitis vinifera) in Russia. Plant Disease, 101(2), 380.

Prieto-Calvo, M. A., Omer, M. K., Alvseike, O., Lopez, M., Alvarez-Ordonez, A., \& Prieto, M. (2016). Comparison of methods for the identification and sub-typing of O157 and non-O157 Escherichia coli serotypes and their integration into polyphasic taxonomy approach. Irish Journal of Agricultural and Food Research., 55(2), 81-90.

Quigley, N. B., Mo, Y. Y., \& Gross, D. C. (1993). syrD is required for syringomycin production by Pseudomonas syringae pathovar syringae and is related to a family of ATP-binding secretion proteins. Molecular Microbiology, 9, 787-801.

Renick, L. J., Cogal, A. G., \& Sundin, G. W. (2008). Phenotypic and genetic analysis of epiphytic Pseudomonas syringae populations from sweet cherry in Michigan. Plant Disease, 92, 372-378.

Sarkar, S. F., \& Guttman, D. S. (2004). Evolution of the Core genome of Pseudomonas syringae, a highly clonal, endemic plant pathogen. Applied and Environmental Microbiology, 70, 1999-1012.
Schaad N.W., Jones J.B. \& Chun W. (2001) Laboratory guide for identification of plant pathogenic bacteria. St Paul, MN, USA, $373 \mathrm{p}$.

Scortichini, M., Marchesi, U., Dettori, M. T., \& Rossi, M. P. (2003). Genetic diversity, presence of the $s y r B$ gene, host preference and virulence of Pseudomonas syringae pv. syringae strains from woody and herbaceous host plants. Plant Pathology, 52, 277-286.

Seemüler E. \& Arnold M. (1978). Pathogenicity, syringomycin production and other characteristics of pseudomonad strains isolated from deciduous fruit trees. Proceedings $4^{\text {th }}$ international conference of plant pathogenic Bacteria, Angers, 703710 .

Sobiczewski P. (1984). Etiology of sour cherry bacterial canker in Poland. Fruit Science Reports XI, 169-180.

Sorensen, K. N., Kim, K.-H., \& Takemoto, J. Y. (1998). PCR detection of cyclic lipodepsinonapeptide-producing Pseudomonas syringae pv. syringae and similarity of strains. Applied and Environmental Microbiology, 64, 226-230.

Tamura, K., Peterson, D., Peterson, N., Stecher, G., Nei, M., \& Kumar, S. (2011). MEGA5: Molecular evolutionary genetics analysis using maximum likelihood, evolutionary distance, and maximum parsimony methods. Molecular Biology and Evolution, 28, 2731-2739.

Tostes, G. D. O., de Paula Araujo, J. S., Farias, A. R. G., Frade, D. A. R., \& Olivares, F. L. (2014). Detection and cellular localization of Xanthomonas campestris pv. viticola in seeds of commercial 'red globe' grapes. Tropical Plant Pathology, 39(2), 134-140.

Weisburg, W. G., Barns, S. M., Pelletier, D. A., \& Lane, D. J. (1991). 16S ribosomal DNA amplification for phylogenetic study. Journal of Bacteriology, 173, 697-703.

Whitelaw-Weckert, M. A., Whitelaw, E. S., Rogiers, S. Y., Quirk, L., Clark, A. C., \& Huang, C. X. (2011). Bacterial inflorescence rot of grapevine caused by Pseudomonas syringae pv. syringae. Plant Pathology, 60, 325-337.

Woźniak, M., Gałąza, A., Tyśkiewicz, R., \& Jaroszuk-Ściseł, J. (2019). Endophytic Bacteria potentially promote plant growth by synthesizing different metabolites and their phenotypic/physiological profiles in the Biolog GEN III MicroPlate $^{\mathrm{TM}}$ test. International Journal of Molecular Sciences, 20, 5283. https://doi.org/10.3390/ijms20215283.

Villela, J. G. A., Ritschel, P., Barbosa, M. A. G., Baccin, K. M., Rossato, M., Maia, J. D., \& Ferreira, M. A. (2019). Detection of Xanthomonas citri pv. viticola on grapevine by real-time PCR and BIO-PCR using primers designed from pathogenicity and xanthomonadin gene sequences. European Journal of Plant Pathology, 155(2), 445-459.

Vauterin, L., Hoste, B., Kersters, K., \& Swings, J. (1995). Reclassification of Xanthomonas. International Journal of Systematic Bacteriology, 45(3), 472-489.

Yoon, S. H., Ha, S. M., Kwon, S., Lim, J., Kim, Y., Seo, H., \& Chun, J. (2017). Introducing EzBioCloud: A taxonomically united database of 16S rRNA and whole genome assemblies. International Journal of Systematic and Evolutionary Microbiology, 67, 1613-1617.

Zhang, J. H., Ouigley, N. B., \& Gross, D. C. (1995). Analysis of the $\operatorname{syr} B$ and $\operatorname{syr} C$ genes of Pseudomonas syringae pv. syringae indicates that syringomycin is synthesized by thiotemplate mechanism. Journal of Bacteriology, 177, 4009-4020. 